\title{
Assessment of response to cerebrospinal fluid tap test for normal pressure hydrocephalus: how we do it
}

\author{
Christopher Nnaemeka Osuafor, Lorraine Kyne
}

Medicine for the Older Person, Mater Misericordiae University Hospital, Dublin, Ireland

\section{Correspondence to} Dr Christopher Nnaemeka Osuafor, chrisosuafor@gmail. com

Accepted 1 August 2016

\section{(1) cossmatk}

To cite: Osuafor CN Kyne L. BMJ Case Rep Published online: [please include Day Month Year] doi:10.1136/bcr-2016217138

\section{DESCRIPTION}

A 65 -year-old woman was referred to our medicine for the older person day hospital with a 2-year history of frequent falls and progressive memory decline. On examination, she was cautious in her gait, slightly leaning to her left side and very unsteady on turning. MRI of her brain revealed prominence of third and lateral ventricles and increased surrounding signal intensity suggestive of normal pressure hydrocephalus (NPH) (figure 1). She consented to a video-recorded cerebrospinal fluid (CSF) tap test (TT) with removal of $50 \mathrm{~mL}$ of CSF. Pre and post (2-hour and 2-day) assessments are shown in table 1.

Post CSF TT, she had a 33.3\% improvement in the Timed Up and Go Test (TUGT), a less likely tendency to fall and a smoother turn (videos 1 and 2). She subsequently underwent a CSF ventriculoperitoneal shunt procedure with remarkable improvement in her mobility.

NPH is a syndrome which consists of a triad of gait disturbance, cognitive dysfunction and urinary symptoms. Owing to its potentially treatable nature, the selection of patients who may benefit from CSF shunt surgery is important. ${ }^{1}$ The most widely used prognostic test to assess candidacy for shunt placement is the CSF TT. ${ }^{2}$ This procedure is proven to have a high positive predictive value

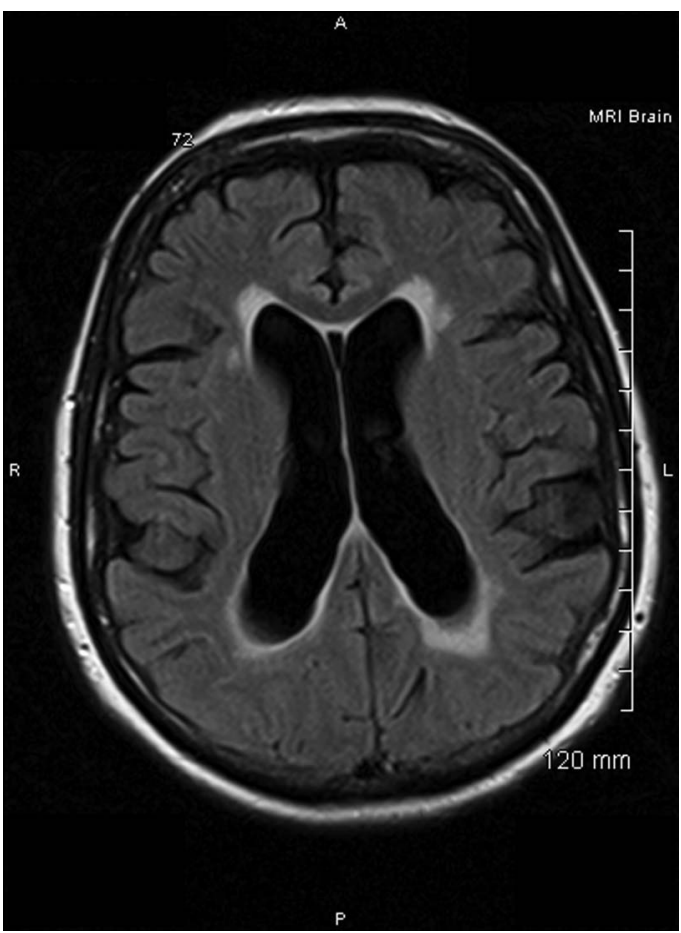

Figure $1 \mathrm{MRI}$ of the brain showing prominence of ventricles.
Table 1 Result of assessment of response to CSF TT

\begin{tabular}{|c|c|c|c|}
\hline & $\begin{array}{l}\text { Before CSF } \\
\text { TT }\end{array}$ & $\begin{array}{l}2 \text { hours } \\
\text { after CSF TT }\end{array}$ & $\begin{array}{l}2 \text { days } \\
\text { after CSF } \\
\text { TT }\end{array}$ \\
\hline MMSE & $18 / 30$ & $19 / 30$ & $20 / 30$ \\
\hline ACE-R & $58 / 100$ & $68 / 100$ & $70 / 100$ \\
\hline TUGT & $18 \mathrm{~s}$ & $12 \mathrm{~s}$ & $8 \mathrm{~s}$ \\
\hline $\begin{array}{l}\text { Number of steps } \\
\text { taken for TUGT }\end{array}$ & 16 & 12 & 10 \\
\hline $\begin{array}{l}\text { Clinical } \\
\text { observation }\end{array}$ & $\begin{array}{l}\text { Cautious } \\
\text { ataxic gait } \\
\text { Near fall on } \\
\text { turn }\end{array}$ & $\begin{array}{l}\text { Steady } \\
\text { confident } \\
\text { gait } \\
\text { Smooth turn }\end{array}$ & $\begin{array}{l}\text { Smooth } \\
\text { gait } \\
\text { Perfect on } \\
\text { the turn }\end{array}$ \\
\hline
\end{tabular}

ACE-R, Addenbrooke's Cognitive Examination-Revised; CSF, cerebrospinal fluid; MMSE, Mini Mental State Examination; TT, tap test; TUGT, Timed Up and Go Test.

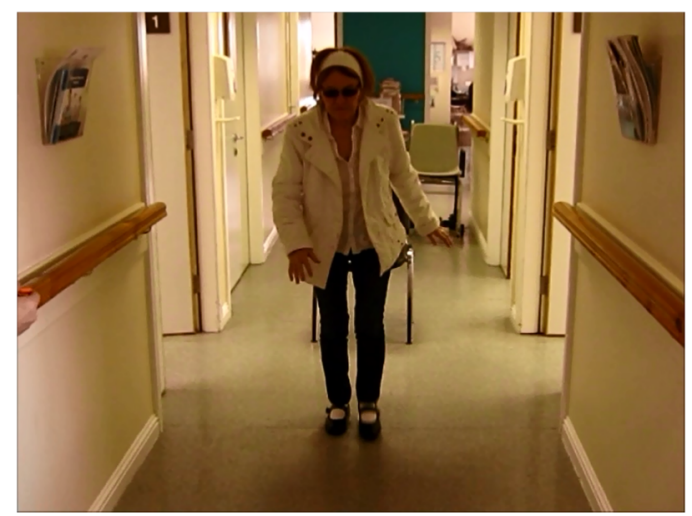

Video 1 Pre cerebrospinal fluid tap test Timed Up and Go Test.

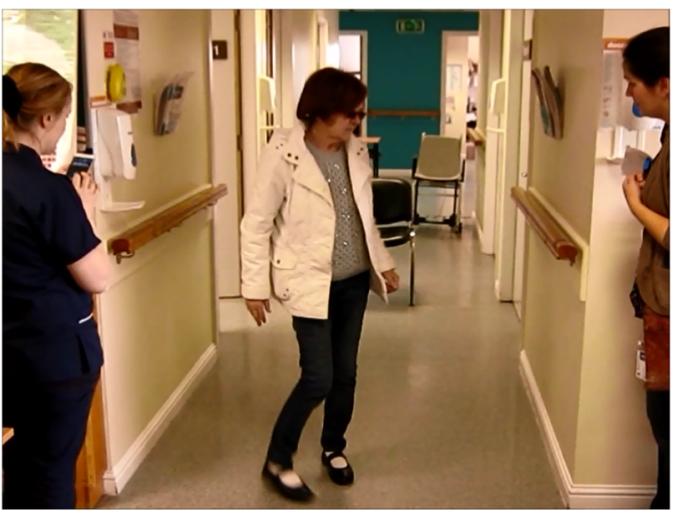

Video 2 Post cerebrospinal fluid tap test Timed Up and Go Test.

when correlated with successful shunt surgery. ${ }^{3}$ The goal of a standard CSF TT should be to detect change in symptoms as efficiently as possible and should be extended for up to 2 days when the suspicion is high. 


\section{Learning points}

- The cerebrospinal fluid (CSF) TT has diagnostic and prognostic value in investigating suspected cases of normal pressure hydrocephalus.

- It is relatively easy to perform in an outpatient or a day-hospital setting.

- Standardised, reproducible measurement of gait speed and cognition should be measured pre and post CSF TT (ideally at 2 hours and at 2 days) and the patient should be video recorded if possible.
Acknowledgements The authors would like to acknowledge Mater Misericordiae University Hospital's Medicine for the Older Person department nursing staff who assisted with patient assessment.

Competing interests None declared.

\section{Patient consent Obtained.}

Provenance and peer review Not commissioned; externally peer reviewed.

\section{REFERENCES}

1 Kang K, Hwang SK, Lee HW. Shunt-responsive idiopathic normal pressure hydrocephalus patient with delayed improvement after tap test. J Korean Neurosurg Soc 2013;54:437-40.

2 Ravdin $L D$, Katzen $H L$, Jackson $A E$, et al. Features of gait most responsive to tap test in normal pressure hydrocephalus. Clin Neurol Neurosurg 2008;110:455-61.

3 Wikkelsø C, Andersson H, Blomstrand C, et al. The clinical effect of lumbar puncture in normal pressure hydrocephalus. J Neurol Neurosurg Psychiatry 1982;45:64-9.

Copyright 2016 BMJ Publishing Group. All rights reserved. For permission to reuse any of this content visit http://group.bmj.com/group/rights-licensing/permissions.

BMJ Case Report Fellows may re-use this article for personal use and teaching without any further permission.

Become a Fellow of BMJ Case Reports today and you can:

- Submit as many cases as you like

- Enjoy fast sympathetic peer review and rapid publication of accepted articles

- Access all the published articles

- Re-use any of the published material for personal use and teaching without further permission

For information on Institutional Fellowships contact consortiasales@bmjgroup.com

Visit casereports.bmj.com for more articles like this and to become a Fellow 